\title{
Features of the formation of the sphere of small and medium-sized businesses in the Southern Federal District
}

\author{
Irina Baranova $^{1^{*}}$ and Ludmila Borisova ${ }^{1}$ \\ ${ }^{1}$ Don State Technical University, 344010, Gagarina square, 1, Rostov-on-Don, Russia
}

\begin{abstract}
Small and medium-sized businesses have great potential, which is revealed in the conditions of a developing economy. The article examines the formation of medium-sized businesses in the Southern region, as well as the prospects for its development in the current economic environment. The article considers the branch structure of entrepreneurship. The problems of the peculiarities of the formation of small and medium-sized enterprises (SMEs), the achievement of competitiveness in the market are along with the actual scientific research of the modern development of Russian regions. Regional entrepreneurship is an important component of any region. Regional entrepreneurship is influenced by various factors and spatial conditions. The analysis of the current state and future development of business in the southern region is carried out. Attention is paid to the regulatory framework, lending, property and other issues of small and medium-sized businesses in the southern region. The share of SMEs in the country's gross domestic product has declined due to the crisis and measures to combat the pandemic. High investment risks and a low level of trust limit the opportunities for business development. The ways of improving the working conditions of entrepreneurs, the legislative framework and other related factors are proposed.
\end{abstract}

\section{Introduction}

Medium and small-sized businesses in the southern Federal District are a relatively new economic phenomenon that emerged 25 years ago. In the recovery period of the $1990 \mathrm{~s}$, the sphere of small and medium-sized enterprises (SMEs), as well as economic reforms, developed ambiguously and undulatively. Small and medium-sized enterprises were the first and for a long time the only form of production and trade. Historically, small and medium-sized businesses were independent economic activities that focused on the internal, rather than the external market of goods (services), preserving this feature to a large extent until our times. Only in 2007, the concept of "medium-sized business" was introduced by law. This is due to the fact that measures of state support for SMEs at all levels of government in these years were more declared than actually implemented in practice. Currently, small and medium-sized businesses have received their sufficient development

* Corresponding author: bariv@,bk.ru 
and are the most important way of doing business. More than a third of the gross regional product is created by such organizations. The small business sector is mainly focused on trade and the providing services to the population [1].

The Southern Federal District is the most compact among the districts of Russia. The population of the district is about 23 million people. The Southern Federal District is one of the largest recipients of the Federal Fund for financial support of the subjects. In the southern district, there are all the necessary conditions for the effective functioning and formation of medium-sized businesses.

Medium and small businesses are an important part of any state and play a significant role in it. This type of small business exists due to local environmental conditions, consumer preferences, and the region's specific specialization. The development of such enterprises depends on the availability of funds and the demand of the population in the region, the development of tourist relations, as well as other factors [2, 3].

Medium and small-sized businesses are an integral part of the economic life of any state, which plays one of the most important roles in it. SMEs make a significant contribution to providing employment, expanding the consumer sector, saturating the market with goods and services, and supporting economic growth in general.

In the legal and economic literature, attention is focused on the characteristics that distinguish small and medium-sized businesses. Such signs are:

- a relatively small market for the product, which does not allow the company to significantly influence the price and volume of the product;

- personal management, which assumes that the manager (owner) themselves take part in the management of the business.

Medium and small businesses in general include:

- business companies, partnerships and partnerships;

- production and consumer cooperatives;

- peasant (farm) farms;

- individual entrepreneurs.

These entities must meet the aspects of the number of workers and the amount of income for the year. Moreover, the income should be taken into account according to the rules of tax accounting, that is, take into account the amount from sales and non-operating income.

In Russia, organizations are classified as medium and small-sized businesses according to the value of two main indicators: the amount of income and the number of people in the company. In Russia, the following criteria for the type of enterprise are used for statistics:

- medium-sized enterprises - legal entities with the number of employees 101 to 250 employees and annual revenue does not exceed 2 billion.

- small businesses face legal by number of employees from 16 to 100 people, and an annual income of not more than 800 million rubles.

- micro-include a legal entity with the number of employees, which up to 15 people, and an annual income of 120 million rubles [4].

In the economic literature, the problems of the market and entrepreneurship are reflected in the books-works of Balatsky E. R., Roubaix V. A., Orlov A.V. Vilensky A.V., Kolesnikova L. A. and others wrote about the importance and necessity of state support for small businesses. Andreeva O. P., Aparina N. F., Blinov A. O., Bragina E. V. were engaged in the study of the regional aspect of small business development. The problems of modern entrepreneurship are reflected in the works of foreign scientists, such as R. Cantillon, E. Chamberlin, S. Shane, W. Baumol, E.Torosyan. The topic of improving the work of small and medium-sized businesses was actively studied by Russian and foreign scientists, but it was not well studied, so it is still in the focus of attention of modern scientists and practitioners [5]. 


\section{Methods}

The basis for writing the theoretical and methodological part of the article was the existing legislative framework (laws, decrees of the President of the Russian Federation, Government resolutions, current norms and regulations) concerning the functioning and development of small and medium-sized businesses. In the study of this topic, methods of comparative, logical analysis, and expert assessments were used. The database for the study was made up of official federal state statistics, regulatory and reference information, and regional sources. The concepts of modern management science are widely used in the research. The main methodological principles are based on the fundamental principles of Russian and foreign specialists in economics and management who study issues related to small and medium-sized businesses. Literature sources were studied, documents were examined, identified signs and phenomena related to SMEs were analyzed, and appropriate conclusions were drawn.

\section{Results}

Small business in the Southern Federal District differs from most foreign countries, as well as from Russia as a whole. The features of this sector include:

- combining several types of activities within a single enterprise;

- low technological equipment;

- a sufficiently high level of personnel qualification and a low level of management;

- ability to adapt to a difficult economic situation;

- lack of development of the system of information and advisory services;

- the structure of support for small enterprises is not sufficiently developed.

Any business activity consists of components that interact with each other. These can be subjects, objects, or processes. Figure 1 shows the relationship between the components of entrepreneurship.

Technologies can be represented by patents, technical means, licenses, etc. Society can be understood as social institutions, population, and social groups. Nature includes natural resources and environmental protection measures. Management as a process interacts on risks, business processes. The economy influences business activity by the processes of consumption and exchange of products, economic growth, and distribution. With the help of politics, interaction takes place between the authorities and business, legislation.

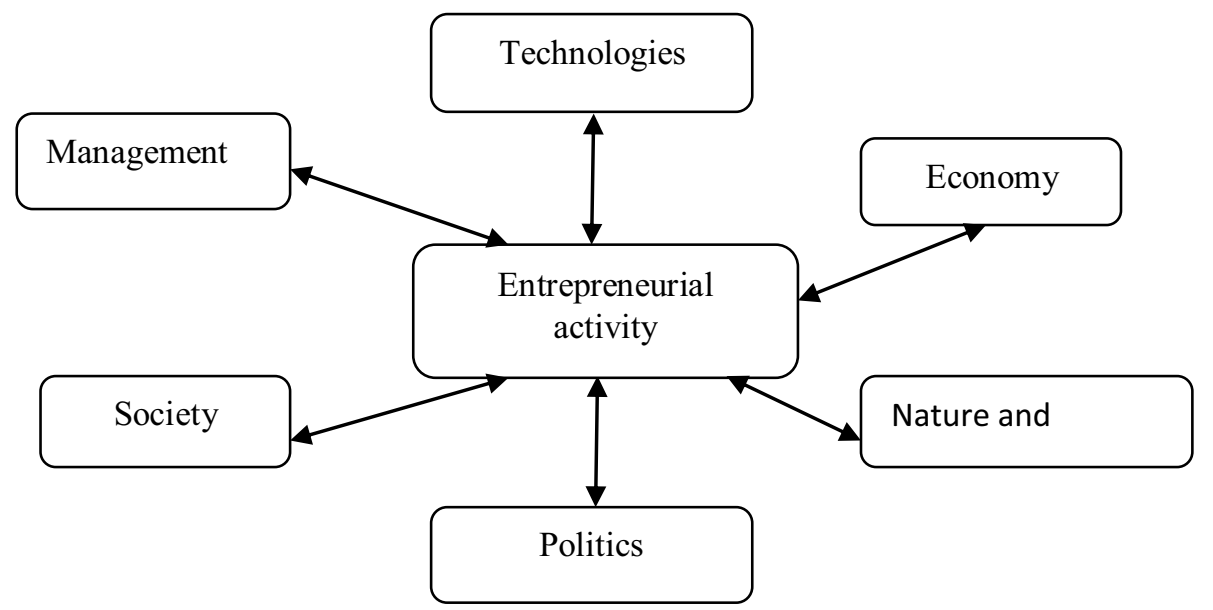

Fig. 1. The relationship between the components of entrepreneurship. 
All the elements are interconnected and cannot exist without each other, having a direct impact on small and medium-sized businesses.

Small and medium-sized enterprises can be divided into such types as production, financial, advisory and commercial. They overlap and may be closely contained in each other [Figure 2].

In the difficult conditions of 2020, the formation of small businesses was possible only with state support and management, as well as the degree of development of factors of production (capital market, labor market, etc.) [6]

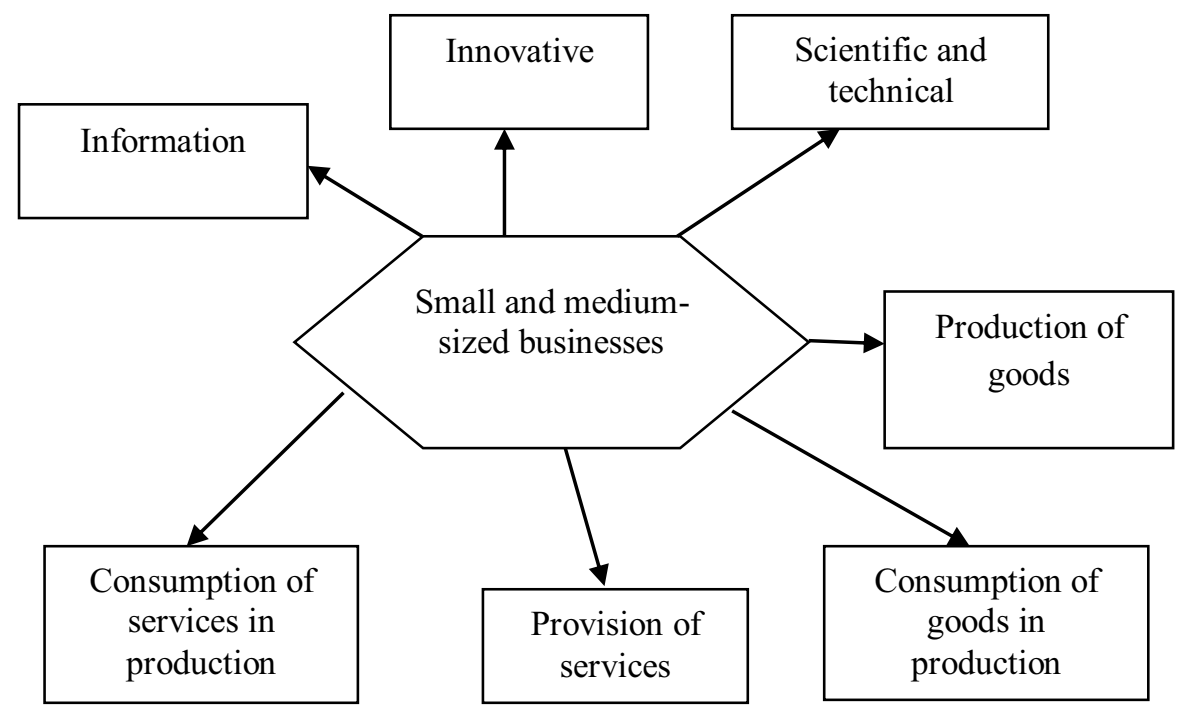

Fig. 2. Types of SMEs in terms of production.

In the field of small business, most of all innovations are implemented, which contributes to the growth of GDP, as well as the creation of additional jobs. In Russia, the regulatory and legal framework for state support of small and medium-sized businesses has been formed. Currently, a number of financial support programs are being implemented that provide entrepreneurs from different regions of the country, including the Southern Federal District, with subsidies to reimburse the cost of doing business or a loan on preferential terms. For small entrepreneurs, special tax regimes are provided, which allow optimizing accounting and tax payments [7].

In 2018, the share of medium and small-sized businesses decreased to $20,2 \%$ of the entire economy. Based on RBC data for 2019, the largest number of working citizens are SMEs in the sectors related to real estate operations (95\%), professional, scientific and administrative activities (55\%), trade (50\%), information and communication (47.6\%), restaurant and hotel business (35.2\%) [Fig. 3].

It should be noted on this issue that small industrial enterprises in the Southern Federal District are located mainly in the manufacturing sector. These are: food production, clothing production, wood processing, production of machinery and equipment.

The industrial production of small enterprises is divided by areas of activity. For example, in the Krasnodar Region, small enterprises mainly produce woodworking machines, baking ovens, and refrigeration equipment. 


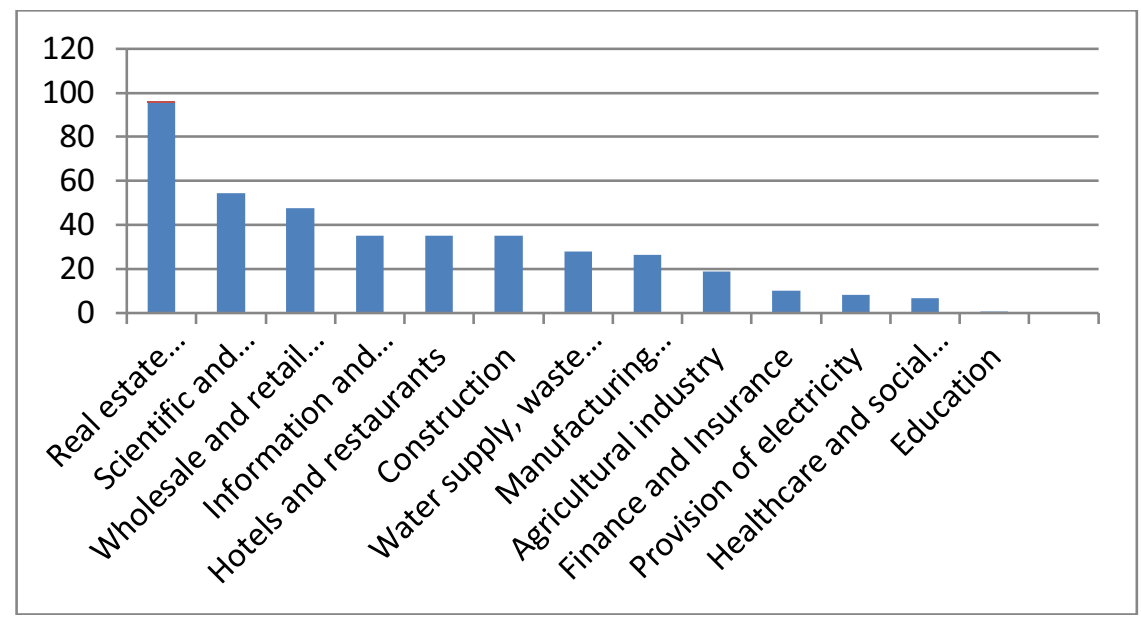

Fig. 3. The number of employed workers in small and medium-sized enterprises (SMEs), \%.

In the Rostov region, small and medium-sized enterprises produce electrical equipment, telephone cables, etc. In the Stavropol Territory, they produce medical equipment and spare parts for it. The Astrakhan region produces metal-cutting and woodworking machines. In the Volgograd region, fiberglass, plastic pipes, enamels, and primers are produced. Dagestan produces wall materials, ceramic tiles. Kabardino-Bolkaria produces metal-plastic doors, while North Ossetia produces doors and window blocks. The entire Southern Federal District actively produces jewelry and handicrafts [8, 9].

The share of employees in large companies in Russia is about $60 \%$ of all employed in the private sector of the economy. For comparison, in Japan $-46 \%$, the UK $-47 \%$, the US $-57 \%$.

Large companies are in all respects responsible for capital and its sustainable involvement in the economy. Small and medium-sized businesses, as an element of rapid economic perception, form innovations and new technological solutions, implementation processes. Looking at the number of people working in production, trade and services, we can conclude that we are close to the world leader in the economy. A strong preponderance is felt on thepart of microenterprises and small businesses. The number of small businesses leads the way.

Medium-and small-sized enterprises operating on "short" money are the most unstable part of the business community. There are 6 million SMEs in Russia, of which about 16 thousand are medium-sized businesses, and more than 223 thousand are small businesses. Small businesses in Russia have been declining in number in recent years. [10].

The SME sector includes not only small enterprises, but also self-employed enterprises. According to Rosstat and Eurostat, Russia has one of the lowest self-employment rates among all those employed in the economy among European countries.

Over the past year, the number of small businesses in the Southern Federal District decreased from 695 to 666 thousand. According to the register of SMEs, the official data of the state statistics in the Rostov region, it decreased by 6 thousand (from 173 to 167 thousand), in the Krasnodar Territory - the number of SMEs decreased by 12 thousand (from 277 thousand to 265 thousand), and in Adygea even increased - from 16,1 to 16,3 thousand.

During the months of the pandemic, more businesses closed than opened. At the same time, enterprises that had existed for several years, which had a significant turnover and staff, were closed. In their place, individual entrepreneurs who opened the same dismissed 
employees. It should be noted that the enterprises that will remain in existence by the end of 2021 will suffer losses and pay significantly less taxes to budgets of all levels [11, 12].

Strict restrictions in the Southern Federal District, which were in effect in the second quarter of 2020, did not allow many SMEs in the region to fulfill their obligations to counterparties, including for the supply of goods due to closed roads. About $40 \%$ of small and medium-sized companies were affected by the coronavirus restrictions and the effects of quarantine, and about $20 \%$ of companies did not return to work..

Mainly, the outflow of SMEs occurred in the field of wholesale and retail trade, cargo transportation and services. It should be noted that the increase in the number of small and medium-sized entities in the field of information and communication. The process of development and functioning of small businesses in the southern Federal District is similar to the process that is observed in the whole country. Similarly to other regions, the most pronounced negative trends are observed in SMEs operating in the field of public catering, hotel and tourism services. It should also be noted that some sectors of the economy have been able to adapt their business to the new realities, and continue to show growth trends. Such enterprises can include small manufacturing enterprises or those works in the field of education. At the end of 2020, we can observe a decrease in the turnover of small enterprises, optimization of the number of employees employed in them [13].

From the COVID-19 2020 digest on SME support, it is noted that small businesses can show flexibility in response to changes in the world, but this feature makes them extremely vulnerable to the negative impact of the economy due to insufficient financial strength. Companies reduce or even stop production due to the introduction of restrictive measures or the termination of the supply of components, the lack of labor, because employees are on sick leave or look after children.

From the data of state statistics on small and medium-sized businesses of the Federal Tax Service, it follows that the number of employees employed in this field in Russia, increased by $1 \%$ in 2020 . The average number of employees in the SME segment (as of 10.0.2021) was 15490144 , which is $1 \%$ higher than last year. The largest number of SMEs as of 10.01.2021 fell on the Central Federal District $-31 \%$ of the total number in Russia and $12 \%$ in the North-Western and Southern Federal Districts [14].

The positive aspects include the fact that small enterprises update fixed assets more actively than a year earlier. Despite the difficult economic situation, small businesses do not reduce the level of wages. On average, in 2020, wages in the Southern Federal District increased by $5 \%$ in small enterprises, and in medium-sized enterprises-by almost $7 \%$. It should be emphasized that SMEs remain an important link in the labor market, providing jobs for $30 \%$ working people in the region. The importance of small businesses for the economy of the Southern Federal District is enormous. Its share exceeds 30\% of the total regional product. There are many regulatory documents and programs that regulate the behavior and existence of small and medium-sized enterprises (SMEs) in economic conditions. The legislation regulating the activities of small and medium-sized enterprises is represented by federal laws, Government resolutions, decrees of the President of the Russian Federation, and other acts of state authorities and local self-government. These are: the Federal Law "On the Development of Small and Medium-sized Businesses in the Russian Federation "(dated 24.07.2007 No. 209-FZ), the Federal Law "On the Protection of the Rights of Legal Entities and Individual Producers in the Exercise of State Control (Supervision) and Municipal Control" (dated 26.12.2008 No. 294-FZ), the Civil Code, the Tax Code of the Russian Federation, the Labor Code of the Russian Federation and many others. In some cases, acts of international law are applicable [15].

The Strategy for the development of small and medium-sized businesses in the Russian Federation for the period up to 2030 defines significant social and economic tasks. These objectives include increasing the share of SMEs in Russia's GDP; it is planned that the 
productivity of small businesses will increase, as well as the number of employees in the SME sector. This Strategy was created for the development of the SME sector. This document is a vector for the development of innovations and the transformation of the economic structure of industries.Also, on the other hand, it is a tool for the development of society, which provides a sufficiently high level of employment of employees and increases their income.

It should be noted that after studying this document, the Strategy assumes not only the growth of the number of small and medium-sized enterprises in the regions, and in Russia as a whole, but also indicators that characterize the quality. The role of SMEs should also be traced in the formation of long-term innovations, which is very important for the development of the Russian economy. To achieve these goals, it is necessary to have significant funds (budget expenditures), as well as changes in the structure of institutions. These include the creation of new technologies for the development of SMEs, a single support center, affordable loan funds, and qualified personnel [16].

One of the priorities for the development of small and medium-sized businesses in the southern region is the transition to an innovative model. Small businesses are receptive to innovation, which in turn will help them get out of the crisis more easily. On the territory of the Southern Federal District, international economic forums dedicated to entrepreneurship in the South of Russia and innovation are held repeatedly. The forum discusses issues related to the application of science and technology in small and medium-sized businesses. Grants are paid to small innovative enterprises of the Southern Federal District.

In the southern macroregion, there are a number of business incubators, which are located in the Krasnodar Territory, Rostov and Volgograd regions.

In the Rostov region, for example, the directions of financial support are indicated on the website https://dongarant.ru. The Guarantee Fund of the Rostov Region was created to provide SMEs with access to support infrastructure, credit and other financial resources for business development. The founder of the Fund is the Ministry of Economic Development of the Rostov Region. The Fund helps individual entrepreneurs and legal entities, organizations of infrastructure support for SMEs included in the Unified Register of Small and Medium-sized Businesses; self-employed citizens and individual entrepreneurs [17].

For SMEs, there are popular pages in the INTERNET sections: portal about companies and business of the Russian Federation https://zachestnyibiznes.ru/ - HONEST BUSINESS; http://novadon.ru -innovation portal of the Rostov region; Innovation Promotion Fund, My Business.RF and others. There is also a financial marketplace for business "Razvitie.RF".

The Unified Register of Small and Medium-sized Businesses is maintained by the tax service on the website https://rmsp.nalog.ru.

\section{Conclusions}

Obviously, it is necessary to pay attention to small businesses. Investments and programs aimed at developing human capital will help transform the balance sheet. The main tools for this are support for business initiatives, regional programs, investment, as well as the overall economic situation. Support for SMEs is not only at the center of public policy, but also occupies a special place in the agenda of combating the consequences of COVID- 19.

For example, the bank "Center-Invest" has started issuing soft loans (at a rate of 3\% per annum) for legal entities and individual entrepreneurs affected by the pandemic. The program is implemented within the framework of the Government of the Russian Federation No. 279 of 27.02.2021. Loans are issued under the guarantee of VEB. RF. You can apply for a preferential loan for small and medium-sized businesses online on the bank's website. State Corporation" VEB. The Russian Federation " within the framework of the employment preservation program provided guarantees in favor of banks for 174.2 
billion rubles. Among such banks are Sberbank, VTB, Promsvyazbank and others. The state will write off the loan and interest if the company maintains employment at the level of $90 \%$ or higher of the state that existed before the outbreak of the pandemic.

SMEs were granted a deferred payment of property tax, transport and land tax, as well as tax paid under the simplified system. In the future, small businesses will start to recover faster than large companies. A sign of this is the dynamics of the labor market. We can see the demand of employees in the construction, automotive and sales businesses.

It is important to say that the growth in the turnover of small and medium-sized enterprises in industry and agriculture will increase not only the tax base, but also create new jobs, and provide solutions to some social problems.

However, it should be noted that the legal framework for the functioning of small and medium-sized businesses is imperfect in many aspects. Thus, there is a need to improve the regulatory documents that currently regulate small businesses, both at the federal and regional levels. In practice, in fact, it is not established which types of support are provided at the expense of budget funds, and which-with partial compensation from budget funds or on a commercial basis, where and under what conditions the state can act as a guarantor of loans for SMEs.

Thus, we can conclude that by supporting small and medium-sized businesses, the state solves the main problems of improving the quality of life of the population, provides budget replenishment at the level of municipalities. The developing competition, which is the main condition for the functioning of small businesses in the market, encourages entrepreneurs to improve the quality of products and introduce innovations. Therefore, effective regulation of small and medium-sized businesses, the application of measures to promote their development, is one of the main state tasks at the present time.

\section{References}

1. V. Dimitrov, L. Borisova, I. Nurutdinova, E3S Web of Conferences, 175, 05027 (2020)

2. N. Serbulova, et al., IOP Conf. Ser.: Earth Environ. Sci., 403, 012127, (2019) DOI: 10.1088/1755-1315/403/1/012127

3. L. Borisova, I. Baranova, O. Bruzhukova, Advances in Economics, Business and Management Research (MTDE 2020), 138, 177-181, (2020) DOI: org/10.2991/aebmr.k.200502.028

4. N. Serbulova, et al., E3S Web Conf., 210, 002-005, (2020) (https://doi.org/10.1051/e3sconf/202021002005)

5. A. Alukhanyan, N. Osadchaya, O. Panfilova, E3S WebofConferences, 175, 13006, (2020)

6. A. Alukhanyan, K. Barmuta, O. Panfilova, D. Borisova, IOP Conference Series: Earth and Environmental Science, 403(1), 012-044, (2019)

7. E. Egorova, I. Mukhomorova, A. Mololetko, P. Solodukha, Social Policy and Sociology, 4(117), 15, 17-25 (2016)

8. V. Plotnikov, Y.Nikitin, A. Volkova, Economics and management, 2 (160), 38-48, (2019)

9. E. Yakovlev, E. Zhuravskaya, Journal of the European Economic Association, 11, 4, 808-83, (2013)

10. A. Young, M. Higgins, D. Lacombe, B. Sell, NBER Working Paper, 20543 (2014)

11. F. Welter, International Small Business Jour, 30, 3, 193-212 (2012) 
12. A. Cullen, Public Contract Law Journal, 41, 3, 703-720 (2012)

13. K.S. Mullakhmetov, R.D. Sadriev, G.S. Gabidinova, Academy of Marketing Studies Journal, 20 (2), 13-19 (2016)

14. S.M. Nikitenko, M.A. Mesyats, O.V. Rozhkova, Earth and Environmental Science, 84(1) (2017) doi:10.1088/1755-1315/84/1/012015.

15. E.M. Akhmetshin, V.L. Vasilev, D.S. Mironov, A.V. Yumashev, A.S. Puryaev, V.V. Lvov, European Research Studies Journal, 21(1), 663-674, (2018)

16. O. Yuldasheva, D. Orekhov, Bulletin of R\&D center of corporate law, management, and venture investment of Syktyvkar State University, 1, 78-91, (2014)

17. E. Schetinina, Y. Doroshenko, N. Ovtcharova, International Business Management, 9 (6), 1074-1078, (2015) 